\title{
Environmental Degradation and Economic Growth in ASEAN-10: The Perspective of EKC Hypothesis
}

\author{
Duc Nha Le ${ }^{a}$ \\ Ton Duc Thang University
}

\begin{abstract}
Environmental issues have been ranked among the most intense debates over the past decades by governments around the world. Sustainable development goals have been top priorities in the working agenda of national cabinets and administrations which questions the chronic trade-off between environment and economic performance. This paper aims at contributing further insights into the above-mentioned linkage to the contemporary literature by testing the validity of the environmental Kuznets curve (EKC) hypothesis. By conducting a panel data analysis on ASEAN-10 countries' statistics of carbon dioxide emissions per capita (COEpc), real gross domestic product per capita (rGDPpc), foreign direct investment inflow (FDlif), trade openness index (TOI), and urbanisation (URB), the findings have empirically confirmed the valid causality running from economic growth, international trade and demographic changes to environmental degradation. Additionally, the existence of an earlier inverted U-shaped and a later $\mathrm{N}$-shaped EKC has been investigated and significantly confirmed the cyclical changes of the eco-enviro trade-off. Also, this paper provides implications for policymakers to consider the cost-benefit issue in the establishment and implementation of economic and environmental protection policies.
\end{abstract}

Keywords: ASEAN-10, carbon emission, economic growth, EKC hypothesis JEL classification: O13, Q56, Q58

\section{Introduction}

Along with the rising concern of Sustainable Development Goals (SDGs) increasingly prioritised in policy objectives of worldwide nations, the environmental issue which is considered as one of the three pillars of sustainable development has been taken into serious account by diverse stakeholders and the entire community (Carley \& Christie, 2017; Fulekar, Pathak, \& Kale, 2014; Rowledge et al., 2017). Among relevant areas, climate change and its concomitant global warming are the grand challenges facing the most vulnerable countries in Africa and Asia, especially the Southeast Asian region (Allison et al., 2009; Amran, Ooi, Wong, \& Hashim, 2016; Ford et al., 2015; Loo, Billa, \& Singh, 2015; Saito, 2013). Of the main causes of those environmentally-

a Faculty of Business Administration, Ton Duc Thang University, No. 19 Nguyen Huu Tho Street, Tan Phong Ward, District 7, Ho Chi Minh City, Viet Nam. Email: leducnha@tdtu.edu.vn ORCID 0000-0002-7601-2046

Article Info: Received 10 September 2018; Revised 31 January 2019; Accepted 25 February 2019 https://doi.org/10.22452/MJES.vol56no1.3 
destructive phenomena, the emission of carbon dioxide $\left(\mathrm{CO}_{2}\right)$ has been blamed for most of the cases (Ghosh, 2010; Gustavsson et al., 2017; IPCC, 2007; Paul \& Bhattacharya, 2004; Pittock, 2005; Skjærseth \& Wettestad, 2016; Tang \& Tan, 2015). In the case of ASEAN-10 countries, the emission volume has been increasing over the past three decades since the 1990s (Figure 1). Among which, Vietnam has observed an unprecedented economic growth while also generating a large amount of $\mathrm{CO}_{2}$ gas (Al-Mulali, Saboori, \& Ozturk, 2015; Tang \& Tan, 2015; Zimmer, Jakob, \& Steckel, 2015), specifically, the most recent emitted amount of $\mathrm{CO}_{2}$ recorded in 2014 has tripled that recorded two decades ago in 1993, while this figure in Thailand, Malaysia and Philippines has nearly doubled since the 1990s, Lao PDR nearly six times, Cambodia and Myanmar nearly four times.

As can be seen in Figure 1, there is a strong correlation between ASEAN-10 economic growth (measured by GDP per capita US\$, rGDPpc) and COEpc (metric tons per capita) in the observed period. However, it seems that within the ten countries of ASEAN there have been two separate trends showing the two reverse relationships between rGDPpc and COEpc. Specifically, Figure 1 indicates similarities among Indonesia, Cambodia, Lao PDR, Myanmar, Malaysia, Philippines, Thailand and Vietnam which suggest the positive association between the two indicators. Conversely, the situations of Singapore and Brunei Darussalam have shown a negative relationship which seems to suggest the existence of environmental Kuznets curve (EKC) in the higher stage of development of a country (Kasman \& Duman, 2015; Heidari, Katircioğlu, \& Saeidpour, 2015).

In the Vietnamese situation, the call for economic development with low rate of gas emission has been disseminated by high-profile officials of the Vietnamese government. ${ }^{1}$ Carbon dioxide gas has also been officially blamed for most cases of unsustainable development as stated in the Kyoto Protocol and has been placed first among six types of greenhouse gases (GHG) of Kyoto basket consisting of carbon dioxide $\left(\mathrm{CO}_{2}\right)$, methane $\left(\mathrm{CH}_{4}\right)$, nitrous oxide $\left(\mathrm{N}_{2} \mathrm{O}\right)$, hydrofluorocarbons (HFCs), perfluorocarbons (PFCs), and sulfur hexafluoride $\left(\mathrm{SF}_{6}\right)$ (Lin, 2010; Lin \& Sun, 2010).

Figure 2 indicates the domination of $\mathrm{CO}_{2}$ emission fraction in the Kyoto basket of Vietnam as it accounted for almost 44.35 percent on average during the period 20032012. The volume of $\mathrm{CO}_{2}$ emission has also seemed to be positively associated with the GHG emission in most cases of ASEAN-10 countries except for Singapore and Indonesia (Figure 3).

By using data of ASEAN-10 nations, this paper will test whether the causality between economic performance indicators and environment-related measurement exists. In addition, the shape of EKC will be explored and confirmed. Contemporary literature on EKC has also been consolidated as the country scope of this paper confirms the generality of the trade-off between environment and economic growth in economies of ASEAN-10. Various EKC studies have focussed on the context of developed and high-income countries which creates potential room for that of

1 http://nhandan.com.vn/kinhte/item/33876602-huong-toi-mot-nen-kinh-te-co-muc-phat-thai-thap.html, accessed on April 2nd 2018. 

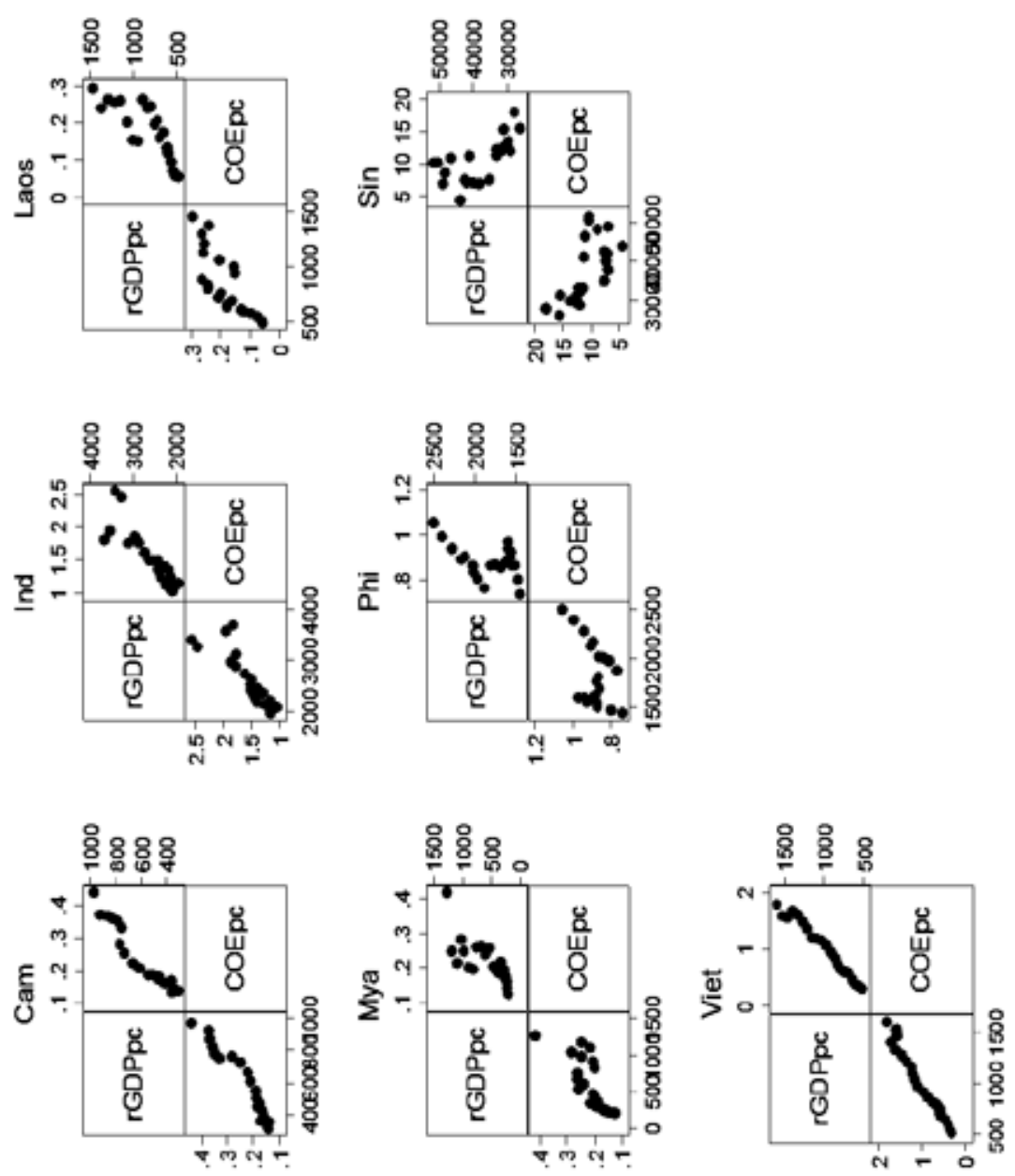

공
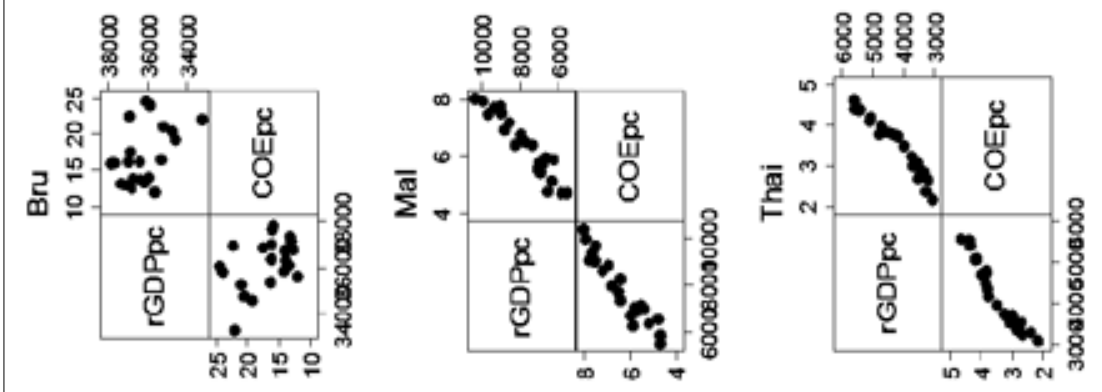

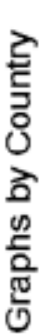


Duc Nha Le

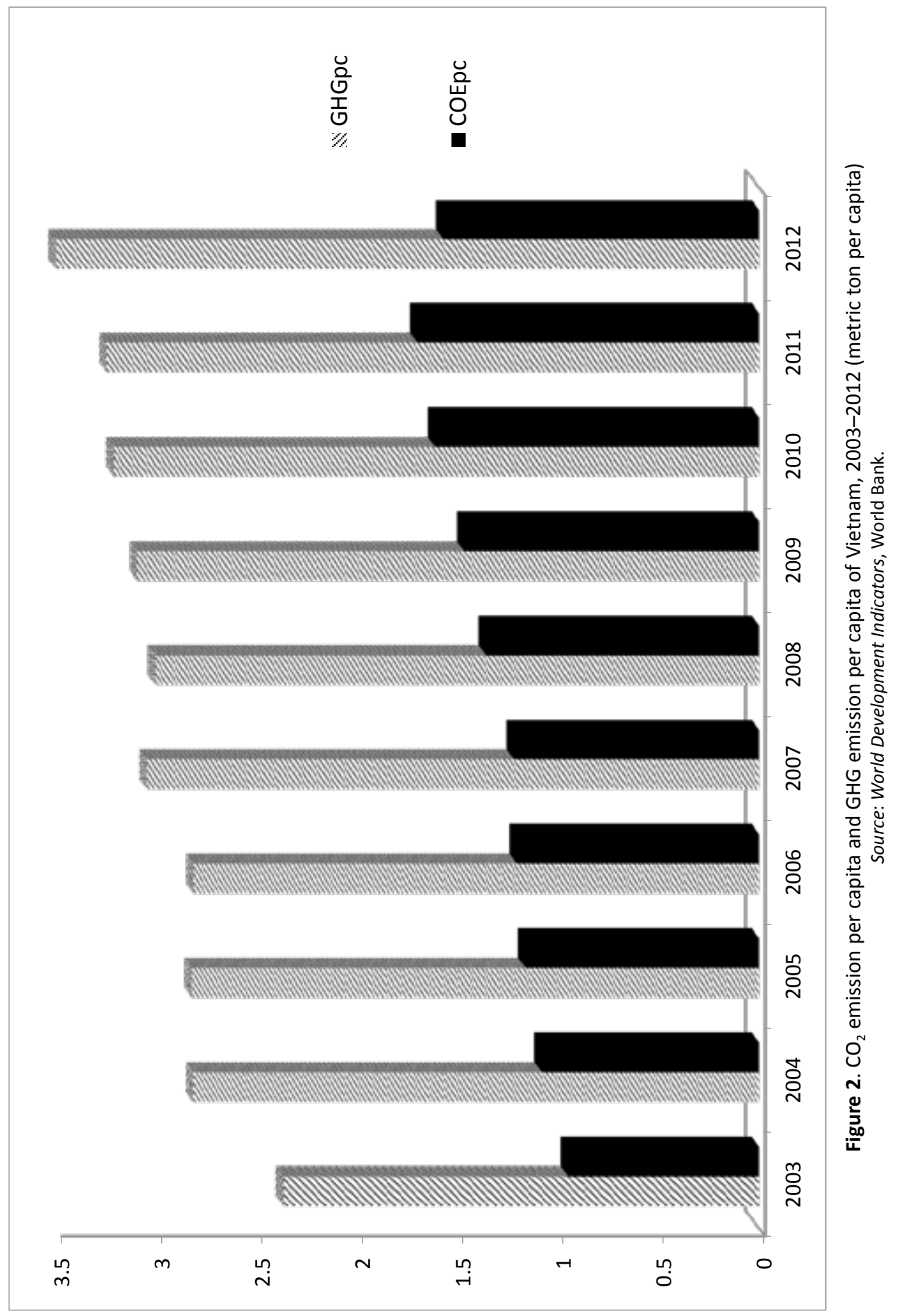



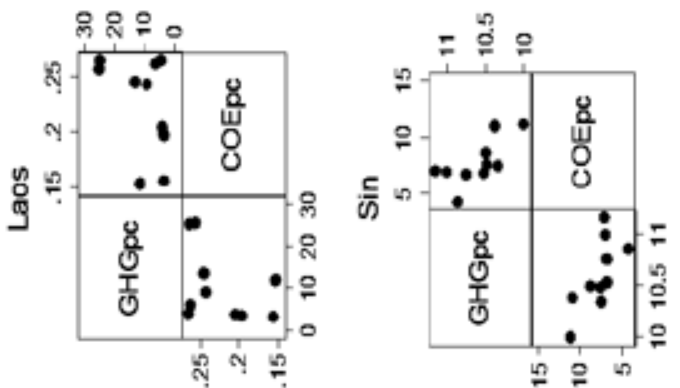

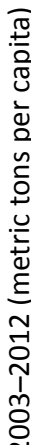
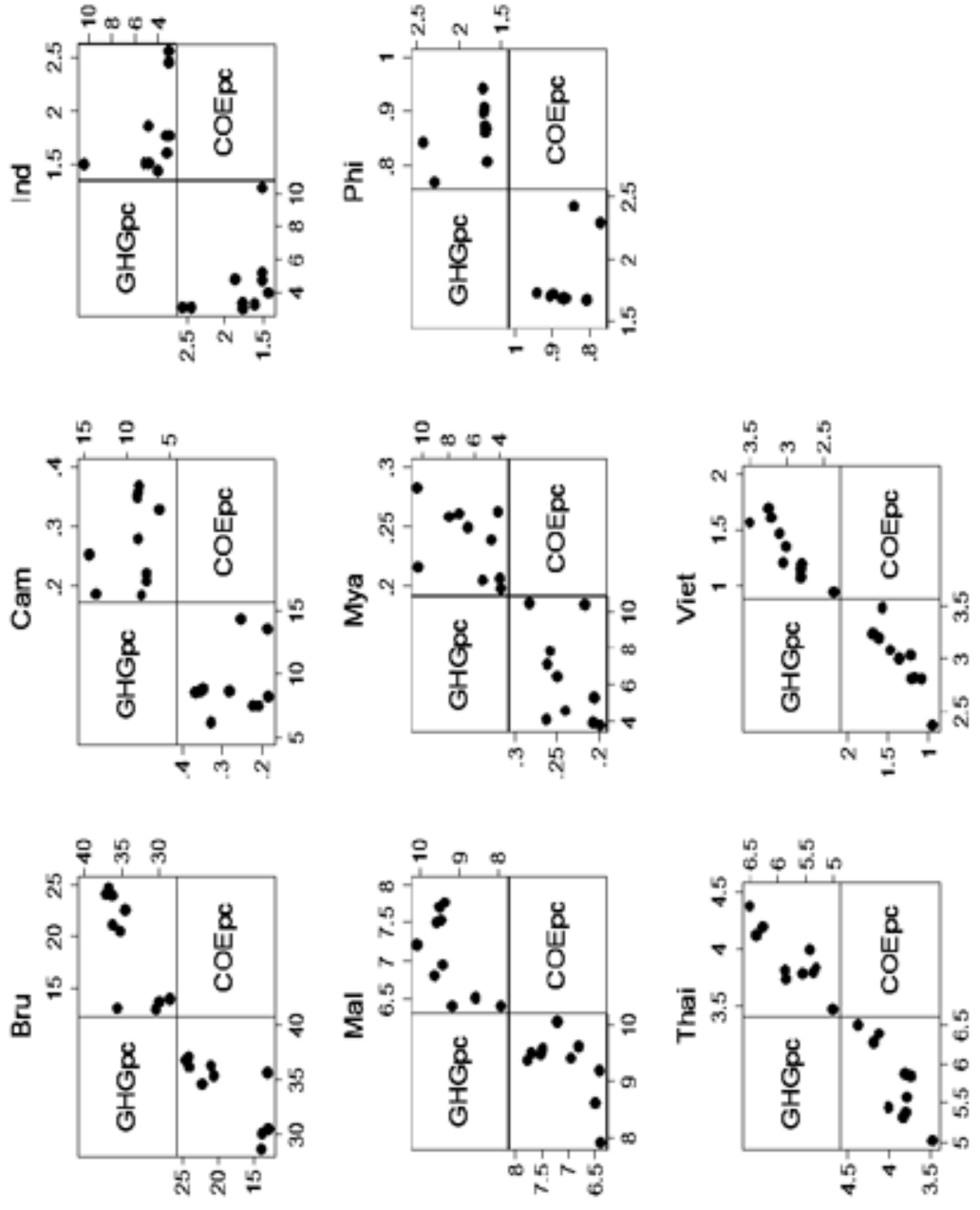
emerging and transitional economies in Asia including ASEAN-10. Furthermore, in economies of tertiary sector-led structure and high-income population like Singapore and Brunei Darussalam in ASEAN-10, the negative linkage may exist. As a result, findings of the paper appear to contribute to the N-shaped EKC argument which reveals the cyclical nature of the trade-off. Besides, international trade is arguably an alleviating measure for the deteriorating air quality which is also empirically proven by the findings of this paper. This would hopefully provide ASEAN-10 governments with a rationale for deeper integration through the establishment of an ASEAN Economic Community (AEC). Moreover, supporting the demographic approach to environmental issues, the paper shows a positive link between population concentration in urban areas and its environmental consequences. Policy implications are recommended based on validated causality which orient national policies towards creating service industries enabling climate, facilitating greater market access, and ensuring sustainable urban planning activities.

The remainder of this paper is structured as follows. Section 2 provides a review of relevant literature which has been built on a platform of eco-enviro interactions. Section 3 includes the proposed research model and measurement to examine those interactions. Section 4 shows results of the quantitative analysis on the established panel data using STATA software. Section 5 includes conclusions and recommendations for the policy-making process especially that of ASEAN-10 countries, and suggests future research directions.

\section{Literature Review}

The relationships or more particularly the trade-off between environmental status measured by COE and indicators of economic performance such as real GDP per capita (rGDPpc), international trade (TOI), inward foreign direct investment (FDlif) and urbanisation (URB) have been analysed and confirmed by various studies applied in diverse global, national, regional or even provincial levels. Carbon emission volume is the direct and best reflective evidence of national industrialisation achievements which have contributed greatly to economic growth thus confirming the valid positive relationship between the two concepts (Asumadu-Sarkodie \& Owusu, 2016; Hartwell, 2017; Omri, Nguyen, \& Rault, 2014; Xu \& Lin, 2017). In the case of emitters achieving miraculously rapid pace of growth, governments tend to promote and incentivise the expansion of economic pie while ignoring the deteriorating environment and ecosystem (Long, Naminse, Du, \& Zhuang, 2015; Xu \& Lin, 2017). Carbon dioxide gas can be emitted from various economic activities especially those in industrial manufacturing sectors which consumed large amounts of fossil fuels, specifically coal and natural gases (Long et al., 2015; Xu \& Lin, 2017).

Inversely, the output has also contributed to the deterioration of environment especially in the early stages of development of emerging economies and economies in transition whereby most sectors appear to depend largely on obsolete production technologies (Lee, Hashim, Ho, Fan, \& Klemeš, 2017; Yang \& Li, 2017) and foreign direct investors seeking natural resources and cost efficiency may target these economies as an external engine for economic growth (Abbes, Mostéfa, Seghir, \& Zakarya, 2015; 
Adams, 2009; Boateng, Hua, Nisar, \& Wu, 2015). However, at later stages when technology advancements have been achieved as a result of economic growth and more demanding stakeholders with improved real income has raised their voices for the need of a healthy living environment (Lee et al., 2017; Yang \& Li, 2017), renewable energy production technologies, which consume solar and biomass energy, electricity and wind power instead of fossil fuels, would replace unclean ones thus mitigating the environmental degradation (Hosseini \& Wahid, 2016).

The above-mentioned two-way interconnectedness which is called bi-directionality has been a hot issue attracting most scholar concerns and has been tested frequently and widely in worldwide geographic regions (Begum, Sohag, Abdullah, \& Jaafar, 2015; Dogan \& Aslan, 2017; Dogan \& Turkekul, 2016; El Montasser, Ajmi, \& Nguyen, 2018; Long et al., 2015; Omri, Nguyen, \& Rault, 2014; Salahuddin, Gow, \& Ozturk, 2015; Tang \& Tan, 2015). To consider the trade-off between environmental degradation and economic growth, previous research has tested the EKC hypothesis with the traditional inverted U-shaped in various countries and regions (Bakirtas \& Cetin, 2017; Begum et al., 2015; Danish, Zhang, Wang, \& Wang, 2017; Dogan \& Turkekul, 2016; Pata, 2018; Tang \& Tan, 2015), thus suggesting policy implications for nations in pursuit of SDGs. Nevertheless, separate and comprehensive attention to the presence of EKC in ASEAN countries have not been paid adequately enough as this region is an emerging vibrant pole in the multipolar world arena (Al-Mulali, Saboori, \& Ozturk, 2015; Al-Mulali, Choong, Low, \& Mohammed, 2015; Borhan, Ahmed, \& Hitam, 2012; Chandran \& Tang, 2013; Katircioğlu, 2014; Lean \& Smyth, 2010; Saboori, Sulaiman, \& Mohd, 2012; Saboori \& Sulaiman, 2013; Zhu, Duan, Guo, \& Yu, 2016).

To include external variables which may affect the central causality, it has been argued that other economic performance indicators should be added to the research model. Firstly, the positive relationship between environmental performance (carbon emission and its major antecedent - energy consumption) and investment has been statistically confirmed by most recent research (Alshehry \& Belloumi, 2015; Azam, Khan, Bakhtyar, \& Emirullah 2015; Lau, Choong, \& Eng, 2014; Omri, Nguyen, \& Rault 2014; Pao \& Tsai, 2011; Tang \& Tan, 2015; Zaman, Shahbaz, Loganathan, \& Raza, 2016). In these studies, scholars have posited that inward FDI may be a solution to the lack of capital for economic development as the public purse of many developing countries is not sufficient and domestic savings are weak and restricted. Thus, inward FDI serves as the engine of economic growth for such countries. Also, the flow of this external resources may entail the transfer of technologies, management knowhow and innovative processes, and facilitate market competition and subsequent productivity enhancements which then ultimately spur the economic performance and carbon emission. From the perspective of theories related to foreign direct investment and environmental regulations, among deciding motivations of multinationals behind global strategies, resource-seeking investors may choose developing countries as attractive destinations for offshoring their production facilities with embedded backward and high-carbon emission technologies due to the less strict environmental rules and weaker enforcement which is known as pollution haven hypothesis ( $\mathrm{PHH})$ (Millimet \& Roy, 2016; Shahbaz, Nasreen, Abbas, \& Anis, 2015; Zaman \& Abd-el Moemen, 2017). 
Secondly, international trade can accelerate or hamper the pace of carbon emission as it influences both domestic production and foreign consumption (Al-Mulali, Ozturk, \& Lean, 2015; Bento \& Moutinho, 2016; Ertugrul, Cetin, Seker, \& Dogan, 2016; Kanemoto, Moran, Lenzen, \& Geschke, 2014; Lau et al., 2014; Ren, Yuan, Ma, \& Chen, 2014). Also, the concept of carbon emission embodied in trade has also been an increasingly observed phenomenon (Böhringer, Carbone, \& Rutherford, 2018; Sakai \& Barrett, 2016; Su \& Ang, 2014; Wu, R., Geng, Dong, Fujita, \& Tian, 2016; Yunfeng \& Laike, 2010). In line with this logic, Franzen \& Mader (2018) have pointed out that, in the case of carbon-intensive industries, outsourcing and offshoring activities of multinationals from countries of stricter control over emission to easier ones, which is called carbon leakage, may occur which means that trade flows could significantly affect air quality. To that end, international trade is arguably a contributor to carbon dioxide emission. Additionally, trade openness, which enables simultaneous increases in export and import, may possibly either improve or worsen environmental degradation (Shahbaz, Tiwari, \& Nasir, 2013) due to the three types of trade liberalisation's impacts on environmental quality, specifically scale, technique and composition effects (Shahbaz et al., 2013). Each of these effects performs different associations with carbon emission (Cole \& Elliott, 2003; Zhang, 2012). According to Cole and Elliott (2003), the scale effect means free trade regime enhances both foreign and domestic market access thus expanding the current size of the economy and creating more industrial manufacturing activities which ultimately lead to the worsening environmental quality. In terms of the technique effect, when free trade spurs income and capital accumulation, the production technologies may emit less carbon dioxide gas as a result of the increased investment in technologies to gain higher productivity and the rising demand for a healthy living environment of a richer community of stakeholders. This implies that, ceteris paribus, technique effects will mitigate the environmental degradation as trade is more open. The composition effect is related to the national comparative advantage as each country will specialise in, as a result of free trade, goods which they can produce more efficiently. Various national characteristics lead to diverse comparative advantages which suggest that specialised goods will vary among nations thus the different extent of carbon emission. To sum up, the carbon leakage phenomenon and multi-effect approach have suggested the incorporation of trade openness into the estimation for this paper.

Last but absolutely not least, the expansion of urban population leads to more diverse and concentrated production and consumption activities which contributes significantly to the environmental degradation by emitting a larger amount of $\mathrm{CO}_{2}$ gas (Al-Mulali, Ozturk, \& Lean, 2015; Liddle, 2014; Wang et al., 2016; Wang, Zhang, Kubota, Zhu, \& Lu, 2015; Wu, Y., Shen, Zhang, Skitmore, \& Lu, 2016; Zhang, Liu, Zhang, \& Tan, 2014; Zhang, Liu, Qin, \& Tan, 2017). For example, Wang et al. (2015) have confirmed the urbanisation-emission EKC hypothesis which means the inverted U-shaped curve of this relationship in the OECD (Organization for Economic Co-operation and Development) countries. Danish et al. (2017) and Zhang, Liu, Qin, \& Tan (2017) have posited that nonrenewable energy consumption of urban regions with rapid expansion in China and Pakistan is among the main causes of carbon emission, thus confirming the positive association between urbanisation and environmental degradation. Similarly, $\mathrm{Wu}$, Shen, Zhang, Skitmore, \& Lu (2016) validated the relationship between urbanisation, energy 
intensity (energy consumption per LCU of GDP), energy carbon emission coefficient $\left(\mathrm{CO}_{2}\right.$ emission/energy consumption) and carbon emission in developing countries while stressing that increasing disparity between rural and urban development also worsens the situation.

\section{Research Model and Measurement}

As stated in section 2, a cubic estimation equation has been recommended to validate the causality between environmental degradation and economic growth:

$$
\begin{aligned}
& \operatorname{COEpc}_{i, t}=\beta_{0}+\beta_{1} r G D P p c_{i, t}+\beta_{2} r G D P p c_{i, t}^{2}+\beta_{3} r G D P p c_{i, t}^{3}+\beta_{4} F \operatorname{lif}_{i, t}+\beta_{5} T O I_{i, t}+ \\
& \beta_{6} \cup R B_{i, t}+\varepsilon_{i, t}
\end{aligned}
$$

where the subscript $i=1, \ldots, \mathrm{N}$ denotes the country ( $\mathrm{N}=10$ in this study) and $t=1, \ldots, \mathrm{T}$ denotes the time period, $\varepsilon$ is the error term, COEpc is the annual carbon emission volume (metric tons per capita), rGDPpc is the annual real gross domestic product per capita (thousand US\$), FDlif is the annual foreign direct investment inflow (million US\$), TOI is the annual trade openness index (the sum of exports and imports of goods and services measured as a share of gross domestic product), and URB is the annual urbanisation rate (the number of people living in urban areas as defined by national statistical offices as a share of total population). In the above equation, there are six possible outcomes which reflect the shape of the causal curve as follows:

(i) $\beta_{1}>0, \beta_{2}<0$, and $\beta_{3}>0$ suggests an $\mathrm{N}$-shaped EKC curve;

(ii) $\beta_{1}<0, \beta_{2}>0$, and $\beta_{3}<0$ suggests an inverted $\mathrm{N}$-shaped EKC curve;

(iii) $\beta_{1}<0, \beta_{2}>0$, and $\beta_{3}=0$ suggests a $U$-shaped EKC curve;

(iv) $\beta_{1}>0, \beta_{2}<0$, and $\beta_{3}=0$ suggests an inverted U-shaped EKC curve;

(v) $\beta_{1}>0$, and $\beta_{2}=\beta_{3}=0$ suggests a monotonically increasing linear causality;

(vi) $\beta_{1}<0$, and $\beta_{2}=\beta_{3}=0$ suggests a monotonically decreasing linear causality.

\section{Data Collection and Results Analysis}

Panel data regression will be used in this paper as the collected data includes both time-series and cross-section dimensions (Baltagi, 2008). Panel data has also been applied in recent studies (Ahsan, Man, \& Qureshi, 2016; Alves \& Francisco, 2015). All of the data, collected for the period 1993-2014, has been sourced from World Bank national accounts of ten ASEAN countries including Brunei Darussalam, Indonesia, Cambodia, Lao PDR, Myanmar, Malaysia, Philippines, Singapore, Thailand and Vietnam. The descriptive profile of variables is provided in Table 1.

Table 1. Descriptive statistics of variables

\begin{tabular}{lrrrrr}
\hline Stats & rGDPpc & COEpc & FDlif & TOI & URB \\
\hline Mean & 9.361666 & 4.193468 & 5566.091 & 126.3081 & 46.57305 \\
SD & 14.28231 & 5.72305 & 10750.15 & 94.15814 & 24.64008 \\
\hline
\end{tabular}

Note: SD indicates standard deviation. 
Table 2. Correlation matrix of variables

\begin{tabular}{llllll}
\hline & COEpc & rGDPpc & FDlif & TOI & URB \\
\hline COEpc & 1.0000 & & & & \\
rGDPpc & 0.8276 & 1.0000 & & & \\
FDlif & 0.2463 & 0.5981 & 1.0000 & & \\
TOI & 0.4775 & 0.7163 & 0.6468 & 1.0000 & \\
URB & 0.7740 & 0.8684 & 0.5766 & 0.7639 & 1.0000 \\
\hline
\end{tabular}

The correlations among proposed variables are first tested to determine whether the quantitative analysis is statistically worth employing (Table 2). The central correlation between $r G D P p c$ and COEpc is strongly confirmed as the coefficient is 0.8276, while demographic changes seem to be considerably correlated with both economic growth and environmental degradation as their correlation coefficients are 0.8684 and 0.7740 respectively. Also, the correlation between foreign direct investment and economic growth seems to be relatively significant, specifically at 0.5981 while this may not necessarily be obtained at the expense of the environment as the FDlif-COEpc correlation is only 0.2463 . The impacts of international trade are also statistically significant whose correlations with $r G D P p c$ and COEpc are 0.7163 and 0.4775 respectively. This may pose a possible concern of multicollinearity as the three independent variables FDlif, TOI and URB are $0.6468,0.5766$ and 0.7639 respectively and their variance inflation factor (VIF) figures in the pooled OLS regression are greater than the lower threshold of 2.0 (Sun et al., 2014), specifically at 5.78, 2.92 and 10.89 respectively. Also, the pooled OLS is considered as not able to take into account for the heterogeneity of variables in the case of panel data (Galindo \& Méndez, 2014). Thus, the fixed effects model (FEM) and random effects model (REM) will be used to lessen this phenomenon (Baltagi, 2008). Also, the opposite situations of Brunei Darussalam and Singapore out of the ten ASEAN countries have challenged the use of pooled OLS as this regression method ignores the heterogeneity among individuals in the sample (Baltagi, 2008). Furthermore, the panel data of this research is an unbalanced set which can be analysed by FEM (Qureshi, Ahsan, \& Azid, 2017; Wooldridge, 2015). Also, as the time dimension is limited to 22 consecutive years and the number of spatial observations is ten countries, FEM is considered to be appropriate for panel data analysis of this size (Galindo \& Méndez, 2014) while allowing for examining the changes of $y$-intercept of regressive graphs which is meaningful for cross-country analyses (Galindo \& Méndez, 2014; Gambacorta, Hofmann, \& Peersman, 2014; Wooldridge, 2015). Additionally, the Hausman test is also employed to determine which model, FEM or REM, is chosen (Baltagi, 2008; Wooldridge, 2015).

The Hausman test in Table 3 indicates that the FE models appear to be more appropriate for the cubic estimation function. It appears that the two FE estimations confirm a positive linkage between economic growth and environmental degradation and the alleviating impact of international trade activities on domestic carbon dioxide emission. Nevertheless, in the FE estimation with time-fixed effects incorporated, the shape of the EKC turns out to be linear and the positive relationship between 
Table 3. FEM \& REM analysis results

\begin{tabular}{|c|c|c|c|}
\hline \multirow[t]{2}{*}{ Variables } & \multicolumn{2}{|c|}{ Fixed Effects Model (FEM) } & \multirow{2}{*}{$\frac{\text { Random Effects Model (REM) }}{\text { COEpc }}$} \\
\hline & COEpc & COEpc & \\
\hline rGDPpc & $\begin{array}{c}0.789 * \\
(0.095)\end{array}$ & $\begin{array}{l}-0.225 \\
(0.709)\end{array}$ & $\begin{array}{l}1.850 * * * \\
(0.0000)\end{array}$ \\
\hline rGDPpc ${ }^{2}$ & $\begin{array}{l}-0.058^{* * *} \\
(0.000)\end{array}$ & $\begin{array}{l}-0.029 \\
(0.135)\end{array}$ & $\begin{array}{l}-0.048^{* * * *} \\
(0.000)\end{array}$ \\
\hline rGDPpc ${ }^{3}$ & $\begin{array}{l}0.0007^{* * *} \\
(0.0000)\end{array}$ & $\begin{array}{l}0.0005^{* *} \\
(0.027)\end{array}$ & $\begin{array}{l}0.0003^{* * *} \\
(0.0000)\end{array}$ \\
\hline FDlif & $\begin{array}{c}0.0000 \\
(0.906)\end{array}$ & $\begin{array}{l}-0.0000 \\
(0.834)\end{array}$ & $\begin{array}{l}-0.0000 * * \\
(0.048)\end{array}$ \\
\hline TOI & $\begin{array}{l}-0.011^{* *} \\
(0.03)\end{array}$ & $\begin{array}{l}-0.015^{* *} \\
(0.016)\end{array}$ & $\begin{array}{l}-0.013^{* * *} \\
(0.0000)\end{array}$ \\
\hline URB & $\begin{array}{c}0.084^{*} \\
(0.054)\end{array}$ & $\begin{array}{c}0.074 \\
(0.102)\end{array}$ & $\begin{array}{l}-0.065^{* * *} \\
(0.0000)\end{array}$ \\
\hline Country FE & YES & YES & \\
\hline Year FE & NO & YES & \\
\hline Constant & $\begin{array}{c}25.335 * * * \\
(0.0000)\end{array}$ & $\begin{array}{c}36.824 * * * \\
(0.0000)\end{array}$ & $\begin{array}{l}1.563^{* * *} \\
(0.000)\end{array}$ \\
\hline Observations & 205 & 205 & 205 \\
\hline Hausman test ${ }^{\mathrm{a}}$ (Prob>Chi ${ }^{2}$ ) & 0.000 & 0.0000 & \\
\hline R-squared & 0.942 & 0.948 & 0.908 \\
\hline
\end{tabular}

Notes: $\quad$-value in parentheses: $* * * \mathrm{p}<0.01, * * \mathrm{p}<0.05$, and $* \mathrm{p}<0.1$.

a Hausman test under null hypothesis shows that estimators of FEM and REM are consistent, and if $\mathrm{p}$-value $<0.05$, FEM is more favourable than REM.

urbanisation and environmental degradation is not significant. The incorporation of time-fixed effects into the estimation, on one hand, increases the number of independent variables and decreases the degree of freedom which may consequently weaken the accuracy of parameters and reduce statistical power. In other words, time-fixed effects should be absent from the estimation as the period of 1993-2014 would lead to the incorporation of 20 additional dummy variables into the equation. On the other hand, from the perspective of policy-making activities, the FE model with more valid coefficients allows more implications for practitioners. In addition, two distinct trends of nations in the ASEAN-10 data set as mentioned in Section 1 would be well reflected and explained by the FE model which validates the N-shaped EKC. The N-shaped EKC describes the changing nature of the central causality as the economy further grows, specifically when income gets higher and the economy increasingly applies carbonneutral technologies. Thus, the findings extracted from the FE model without time-fixed effects are selected for subsequent analysis and policy implications.

As reported in Table 3, there is valid causality running from real gross domestic product per capita and its squared and cubic variables, trade openness and urbanisation 
to carbon emission, except for inward foreign direct investment. As questioned in Section 1 when considering the scatter plots of Singapore and Brunei Darussalam in Figure 1, the results in Table 3 reveal the existence of an early inverted U-shaped and $\mathrm{N}$-shaped EKC in the long run (Begum et al., 2015; Fodha \& Zaghdoud, 2010; Heidari et al., 2015). However, in the context of this paper, the slight negative relationship of the two central variables may generate some implications for re-orienting ecosocio policies. Meanwhile, accelerating urbanisation may be the signal of increasing consumption and large clustering production sites. This means overwhelmingly accelerated and ill-planned development may be achieved at the expense of the environment. Interestingly, the findings also explore the negative impact of trade openness on carbon emission which could be found in other previous academic work (Ali, Law, \& Zannah, 2016; Al-Mulali, Ozturk, \& Lean, 2015; Shahbaz, Sbia, Hamdi, \& Ozturk, 2014) and confirm the existence of the carbon emission embodied in trade phenomenon in ASEAN-10 (Böhringer et al., 2018; Sakai \& Barrett, 2016; Su \& Ang, 2014; Wu, Geng, Dong, Fujita, \& Tian, 2016; Yunfeng \& Laike, 2010) or carbon leakage (Franzen \& Mader, 2018). This implies that policies for greater market access and deeper integration, as discussed by Al-Mulali, Ozturk and Lean (2015), can help ASEAN-10 authorities proactively hamper the environmental degradation. Before coming to section 5 of the research, Table 4 provides a summary of valid linkages which have been significantly confirmed by findings of the FE estimations.

Table 4. Summary of causality

\begin{tabular}{|l|c|c|c|c|c|c|}
\hline & rGDPpc & rGDPpc $^{2}$ & rGDPpc $^{3}$ & FDlif & TOI & URB \\
\hline \multirow{2}{*}{$\begin{array}{l}\text { COEpc (without time- } \\
\text { fixed effects) }\end{array}$} & $(+)$ & $(-)$ & $(+)$ & & \multirow{2}{*}{$(-)$} & $(+)$ \\
\cline { 2 - 7 } & \multicolumn{2}{|c|}{ The explored N-shaped EKC } & & & $(-)$ & \\
\hline $\begin{array}{l}\text { COEpc (with time- } \\
\text { fixed effects) }\end{array}$ & & & $(+)$ & & \\
\hline
\end{tabular}

\section{Conclusions and Policy Implications}

This research has confirmed both positive and negative causality between carbon emission and economic growth in the case of ASEAN-10 countries, specifically the inverted U-shaped EKC in the early stages of development and the N-shaped EKC hypothesis in the long run. Also, the findings support policies towards achieving SDGs by enhancing environmental control and protection while encouraging economic activities of low-carbon technologies which limits negative environmental externalities. ASEAN-10 nations can choose alternative energy which is carbon neutral such as nuclear energy, photovoltaic energy, wind, water and geothermal energy to mitigate negative impacts of human economic activities on the environment. In addition, tax policies imposed on carbon emission should also be considered as this may help restrict the emission volume. As the coefficient of the cubic variable of real income appears to be positive, it reveals the cyclical characteristic of the trade-off as a larger 
size of the economy may further deteriorate the environment after just a short time of improvement. It is also critical that policymakers should calculate accurately the local maxima and minima of the N-shaped EKC as these values are the turning points which signal the better and worse prospects of environment consistent with the growth of the economy. This helps governments to synchronize their economic policies with the environmental degradation, specifically as can be seen in Figure 4, when real output has not yet reached the maxima point $\left(0 \rightarrow Y_{1}\right)$, stricter emission restraint needs to be put into effect and a more relaxing one may be considered as advanced production technologies and expanding international trade has alleviated the negative impacts $\left(Y_{1} \rightarrow Y_{2}\right)$, and again, the repetition of the positive causality may occur but at higher levels of carbon emissions $\left(\mathrm{Y}_{2} \rightarrow+\infty\right)$. The existence of an $\mathrm{N}$-shaped EKC has been investigated and significantly confirmed which reveals the cyclical changes of the ecoenviro trade-off and a suggested multi-phase approach to related debates as can be seen in Figure 4.

Additionally, the findings indicate that governments can in one hand accelerate economic growth while mitigating the environmental degradation and on the other hand by promoting greater market access and deeper integration through multilateral and bilateral trade agreements. Trade facilitation policies also need to be further shaped and implemented to diversify and encourage more international business transactions which ultimately result in increased trade openness and the concomitant environmental improvement. Finally, the increase of urban population seems to be a worrisome issue against environmental protection efforts taken by ASEAN-10 governments. This opens up another concern related to spending more public expenditure on basic infrastructure to establish new satellite and peripheral centres for economic development surrounding current large cities in ASEAN-10 countries, which alleviates the pressure of urbanisation on the environment. These newly-established satellite cities can be magnets for rural migrants, thus eliminating

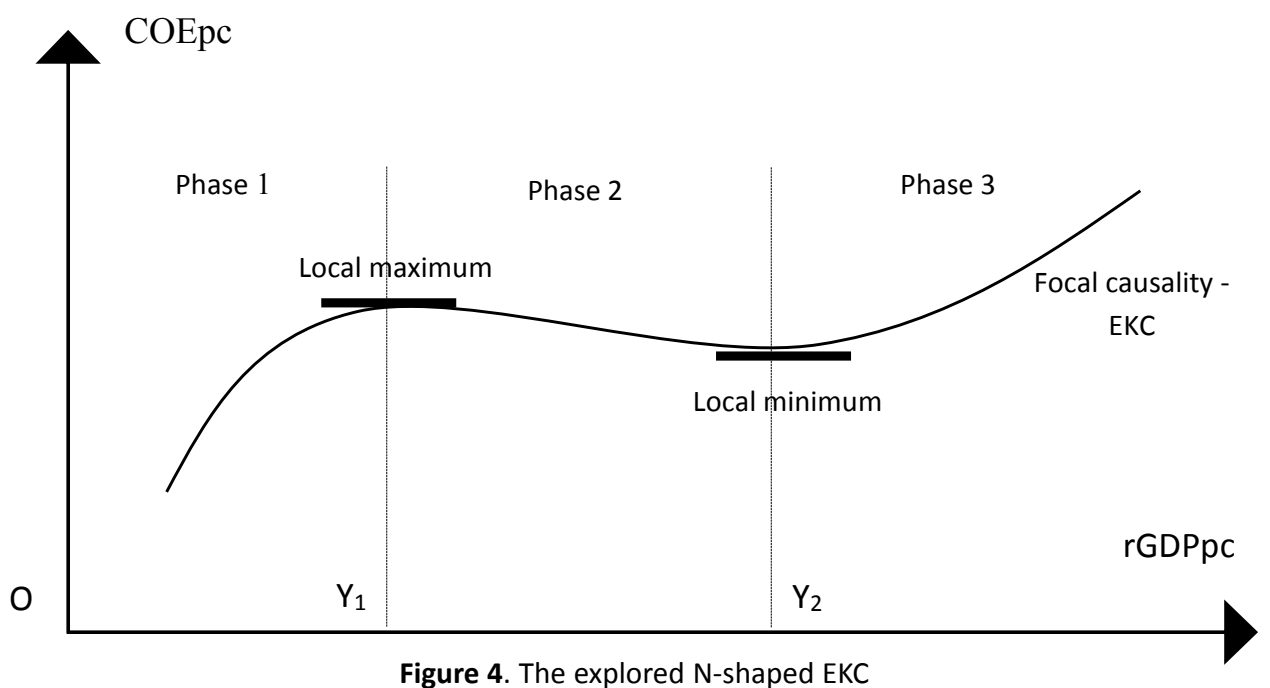


the dense concentration of production and consumption in large cities. Urban planning should also be well-planned with expanded public consultation before the implementation. Obtaining and sustaining the balance between environmental degradation and overwhelmingly accelerated economic growth, accompanied by flourishing urban infrastructure and facilities, should be taken into account by ASEAN-10 countries. Policies towards encouraging efficient energy consumption of households and institutions and use of renewable energy in production should go hand in hand with industrialisation and modernisation strategies to offset the adverse influences of urbanisation on the environment.

This research uses FEM \& REM estimations to test the validity of proposed linkages which can be more deeply examined by other regression methods to panel data sets such as Granger causality test which allows exploring the two-way relationships among variables. Furthermore, the cross-sectional dimension of the data set includes only ten ASEAN economies which may weaken the generality and applicability of the findings, thus including more data of Northeast Asian countries is a future prospect as this allows examining the differences among groups of nations. Also, carbon emission is only one of many indicators of environmental impacts, thus, future research should include more related yardsticks such as energy consumption (per capita), GHG emission (per capita), electricity consumption (per capita), fossil fuels consumption (per capita), energy intensity (energy consumption per LCU of GDP), energy carbon emission coefficient (CO2 emissions/energy consumption), etc. to more comprehensively assess proposed causality between economic performance and environmental impacts, especially the consumption of non-renewable energy as a stepping stone between carbon emission and other economic indicators. Additionally, the nexus of urbanisation and carbon emission also needs to be separately investigated in future research especially the existence of the urbanisation-carbon emission EKC hypothesis. Similar concerns should also be imposed on the relationship between trade and carbon emission as the aggregate impact of three component effects of free trade on the environment may be either positive or negative depending on individual magnitude. Further research needs to calculate the specific value of rGDPpc at turning points of the EKC to help nations better design environmental protection policies in pace with estimated economic growth.

\section{References}

Abbes, S.M., Mostéfa, B., Seghir, G., \& Zakarya, G.Y. (2015). Causal interactions between FDI, and economic growth: Evidence from dynamic panel co-integration. Procedia Economics and Finance, 23, 276-290. https://doi.org/10.1016/S2212-5671(15)00541-9

Adams, S. (2009). Foreign direct investment, domestic investment, and economic growth in Sub-Saharan Africa. Journal of Policy Modeling, 31(6), 939-949. https://doi.org/10.1016/ j.jpolmod.2009.03.003

Ahsan, T., Man, W., \& Qureshi, M.A. (2016). Mean reverting financial leverage: Theory and evidence from Pakistan. Applied Economics, 48(5), 379-388. https://doi.org/10.1080/000368 46.2015.1080802

Ali, H.S., Law, S.H., \& Zannah, T.I. (2016). Dynamic impact of urbanization, economic growth, energy consumption, and trade openness on $\mathrm{CO}_{2}$ emissions in Nigeria. Environmental 
Science and Pollution Research, 23(12), 12435-12443. https://doi.org/10.1007/s11356-0166437-3

Allison, E.H., Perry, A.L., Badjeck, M-C., Neil Adger, W., Brown, K., Conway, D.,...Dulvy, N.K. (2009). Vulnerability of national economies to the impacts of climate change on fisheries. Fish and Fisheries, 10(2), 173-196. https://doi.org/10.1111/j.1467-2979.2008.00310.x

Al-Mulali, U., Choong, W-W., Low, S-T., \& Mohammed, A.H. (2015). Investigating the environmental Kuznets curve (EKC) hypothesis by utilizing the ecological footprint as an indicator of environmental degradation. Ecological Indicators, 48(January), 315-323. https://doi. org/10.1016/j.ecolind.2014.08.029

Al-Mulali, U., Ozturk, I., \& Lean, H.H. (2015). The influence of economic growth, urbanization, trade openness, financial development, and renewable energy on pollution in Europe. Natural Hazards, 79(1), 621-644. https://doi.org/10.1007/s11069-015-1865-9

Al-Mulali, U., Saboori, B., \& Ozturk, I. (2015). Investigating the environmental Kuznets curve hypothesis in Vietnam. Energy Policy, 76(January), 123-131. https://doi.org/10.1016/j.enpol. 2014.11.019

Alshehry, A.S., \& Belloumi, M. (2015). Energy consumption, carbon dioxide emissions and economic growth: The case of Saudi Arabia. Renewable and Sustainable Energy Reviews, 41(January), 237-247. https://doi.org/10.1016/j.rser.2014.08.004

Alves, P., \& Francisco, P. (2015). The impact of institutional environment on the capital structure of firms during recent financial crises. The Quarterly Review of Economics and Finance, 57(August), 129-146. https://doi.org/10.1016/j.qref.2014.12.001

Amran, A., Ooi, S.K., Wong, C.Y., \& Hashim, F. (2016). Business strategy for climate change: An ASEAN perspective. Corporate Social Responsibility and Environmental Management, 23(4), 213-227. https://doi.org/10.1002/csr.1371

Asumadu-Sarkodie, S., \& Owusu, P.A. (2016). Carbon dioxide emission, electricity consumption, industrialization, and economic growth nexus: The Beninese case. Energy Sources, Part B: Economics, Planning, and Policy, 11(11), 1089-1096. https://doi.org/10.1080/15567249.201 6.1217286

Azam, M., Khan, A.Q., Bakhtyar, B., \& Emirullah, C. (2015). The causal relationship between energy consumption and economic growth in the ASEAN-5 countries. Renewable and Sustainable Energy Reviews, 47(July), 732-745. https://doi.org/10.1016/j.rser.2015.03.023

Bakirtas, I., \& Cetin, M.A. (2017). Revisiting the environmental Kuznets curve and pollution haven hypotheses: MIKTA sample. Environmental Science and Pollution Research, 24(22), 1827318283. https://doi.org/10.1007/s11356-017-9462-y

Baltagi, B.H. (2008). Econometric analysis of panel data. Chichester, West Sussex: John Wiley \& Sons.

Begum, R.A., Sohag, K., Abdullah, S.M.S., \& Jaafar, M. (2015). $\mathrm{CO}_{2}$ emissions, energy consumption, economic and population growth in Malaysia. Renewable and Sustainable Energy Reviews, 41(January), 594-601. https://doi.org/10.1016/j.rser.2014.07.205

Bento, J.P.C., \& Moutinho, V. (2016). $\mathrm{CO}_{2}$ emissions, non-renewable and renewable electricity production, economic growth, and international trade in Italy. Renewable and Sustainable Energy Reviews, 55(March), 142-155. https://doi.org/10.1016/j.rser.2015.10.151

Boateng, A., Hua, X., Nisar, S., \& Wu, J. (2015). Examining the determinants of inward FDI: Evidence from Norway. Economic Modelling, 47(June), 118-127. https://doi.org/10.1016/j. econmod.2015.02.018

Böhringer, C., Carbone, J.C., \& Rutherford, T.F. (2018). Embodied carbon tariffs. The Scandinavian Journal of Economics, 120(1), 183-210. https://doi.org/10.1111/sjoe.12211

Borhan, H., Ahmed, E.M., \& Hitam, M. (2012). The impact of $\mathrm{CO}_{2}$ on economic growth in ASEAN 8. Procedia - Social and Behavioral Sciences, 35, 389-397. https://doi.org/10.1016/j.sbspro. 2012.02.103 
Carley, M., \& Christie, I. (2017). Managing sustainable development (2nd ed.). London and New York: Routledge.

Chandran, V.G.R., \& Tang, C.F. (2013). The impacts of transport energy consumption, foreign direct investment and income on $\mathrm{CO}_{2}$ emissions in ASEAN-5 economies. Renewable and Sustainable Energy Reviews, 24(August), 445-453. https://doi.org/10.1016/j.rser.2013.03.054

Cole, M.A., \& Elliott, R.J.R. (2003). Determining the trade-environment composition effect: The role of capital, labor and environmental regulations. Journal of Environmental Economics and Management, 46(3), 363-383. https://doi.org/10.1016/S0095-0696(03)00021-4

Danish, Zhang, B., Wang, B., \& Wang, Z. (2017). Role of renewable energy and non-renewable energy consumption on EKC: Evidence from Pakistan. Journal of Cleaner Production, 156 (July), 855-864. https://doi.org/10.1016/j.jclepro.2017.03.203

Dogan, E., \& Aslan, A. (2017). Exploring the relationship among $\mathrm{CO}_{2}$ emissions, real GDP, energy consumption and tourism in the EU and candidate countries: Evidence from panel models robust to heterogeneity and cross-sectional dependence. Renewable and Sustainable Energy Reviews, 77(September), 239-245. https://doi.org/10.1016/j.rser.2017.03.111

Dogan, E., \& Turkekul, B. (2016). $\mathrm{CO}_{2}$ emissions, real output, energy consumption, trade, urbanization and financial development: Testing the EKC hypothesis for the USA. Environmental Science and Pollution Research, 23(2), 1203-1213. https://doi.org/10.1007/s11356015-5323-8

El Montasser, G., Ajmi, A.N., \& Nguyen, D.K. (2018). Carbon emissions-income relationships with structural breaks: The case of the Middle Eastern and North African countries. Environmental Science and Pollution Research, 25(3), 2869-2878. https://doi.org/10.1007/s11356017-0725-4

Ertugrul, H.M., Cetin, M., Seker, F., \& Dogan, E. (2016). The impact of trade openness on global carbon dioxide emissions: Evidence from the top ten emitters among developing countries. Ecological Indicators, 67(August), 543-555. https://doi.org/10.1016/j.ecolind.2016.03.027

Fodha, M., \& Zaghdoud, O. (2010). Economic growth and pollutant emissions in Tunisia: An empirical analysis of the environmental Kuznets curve. Energy Policy, 38(2), 1150-1156. https://doi.org/10.1016/j.enpol.2009.11.002

Ford, J.D., Berrang-Ford, L., Bunce, A., McKay, C., Irwin, M., \& Pearce, T. (2015). The status of climate change adaptation in Africa and Asia. Regional Environmental Change, 15(5), 801814. https://doi.org/10.1007/s10113-014-0648-2

Franzen, A., \& Mader, S. (2018). Consumption-based versus production-based accounting of $\mathrm{CO}_{2}$ emissions: Is there evidence for carbon leakage? Environmental Science \& Policy, 84(June), 34-40. https://doi.org/10.1016/j.envsci.2018.02.009

Fulekar, M.H., Pathak, B., \& Kale, R.K. (Eds.) (2014). Environment and sustainable development. New Delhi, India: Springer.

Galindo, M-Á., \& Méndez, M.T. (2014). Entrepreneurship, economic growth, and innovation: Are feedback effects at work? Journal of Business Research, 67(5), 825-829. https://doi. org/10.1016/j.jbusres.2013.11.052

Gambacorta, L., Hofmann, B., \& Peersman, G. (2014). The effectiveness of unconventional monetary policy at the zero lower bound: A cross-country analysis. Journal of Money, Credit and Banking, 46(4), 615-642. https://doi.org/10.1111/jmcb.12119

Ghosh, S. (2010). Examining carbon emissions economic growth nexus for India: A multivariate cointegration approach. Energy Policy, 38(6), 3008-3014. https://doi.org/10.1016/j.enpol. 2010.01.040

Gustavsson, L., Haus, S., Lundblad, M., Lundström, A., Ortiz, C.A., Sathre, R.,...Wikberg, P-E. (2017). Climate change effects of forestry and substitution of carbon-intensive materials and fossil fuels. Renewable and Sustainable Energy Reviews, 67(January), 612-624. https://doi. org/10.1016/j.rser.2016.09.056 
Hartwell, R.M. (2017). The industrial revolution and economic growth (vol. 4). Abingdon \& New York: Routledge.

Heidari, H., Katircioğlu, S.T., \& Saeidpour, L. (2015). Economic growth, $\mathrm{CO}_{2}$ emissions, and energy consumption in the five ASEAN countries. International Journal of Electrical Power \& Energy Systems, 64(January), 785-791. https://doi.org/10.1016/j.ijepes.2014.07.081

Hosseini, S.E., \& Wahid, M.A. (2016). Hydrogen production from renewable and sustainable energy resources: Promising green energy carrier for clean development. Renewable and Sustainable Energy Reviews, 57(May), 850-866. https://doi.org/10.1016/j.rser.2015.12.112

IPCC. (2007). Climate Change 2007: The Physical Science Basis. Contribution of Working Group I to the Fourth Assessment Report of the Intergovernmental Panel on Climate Change [Solomon, S., Qin, D., Manning, M., Chen, Z., Marquis, M., Averyt, K.B., Tignor, M., \& Miller, H.L. (Eds.)]. Cambridge, UK \& New York, NY: Cambridge University Press.

Kanemoto, K., Moran, D., Lenzen, M., \& Geschke, A. (2014). International trade undermines national emission reduction targets: New evidence from air pollution. Global Environmental Change, 24(January), 52-59. https://doi.org/10.1016/j.gloenvcha.2013.09.008

Kasman, A., \& Duman, Y.S. (2015). $\mathrm{CO}_{2}$ emissions, economic growth, energy consumption, trade and urbanization in new EU member and candidate countries: A panel data analysis. Economic Modelling, 44(January), 97-103. https://doi.org/10.1016/j.econmod.2014.10.022

Katircioğlu, S.T. (2014). Testing the tourism-induced EKC hypothesis: The case of Singapore. Economic Modelling, 41(August), 383-391. https://doi.org/10.1016/j.econmod.2014.05.028

Lau, L-S., Choong, C-K., \& Eng, Y-K. (2014). Investigation of the environmental Kuznets curve for carbon emissions in Malaysia: Do foreign direct investment and trade matter? Energy Policy, 68(May), 490-497. https://doi.org/10.1016/j.enpol.2014.01.002

Lean, H.H., \& Smyth, R. (2010). $\mathrm{CO}_{2}$ emissions, electricity consumption and output in ASEAN. Applied Energy, 87(6), 1858-1864. https://doi.org/10.1016/j.apenergy.2010.02.003

Lee, C.T., Hashim, H., Ho, C.S., Fan, Y.V., \& Klemeš, J.J. (2017). Sustaining the low-carbon emission development in Asia and beyond: Sustainable energy, water, transportation and lowcarbon emission technology. Journal of Cleaner Production, 146(March), 1-13. https://doi. org/10.1016/j.jclepro.2016.11.144

Liddle, B. (2014). Impact of population, age structure, and urbanization on carbon emissions/ energy consumption: Evidence from macro-level, cross-country analyses. Population and Environment, 35(3), 286-304. https://doi.org/10.1007/s11111-013-0198-4

Lin, B., \& Sun, C. (2010). Evaluating carbon dioxide emissions in international trade of China. Energy Policy, 38(1), 613-621. https://doi.org/10.1016/j.enpol.2009.10.014

Lin, T-P. (2010). Carbon dioxide emissions from transport in Taiwan's national parks. Tourism Management, 31(2), 285-290. https://doi.org/10.1016/j.tourman.2009.03.009

Long, X., Naminse, E.Y., Du, J., \& Zhuang, J. (2015). Nonrenewable energy, renewable energy, carbon dioxide emissions and economic growth in China from 1952 to 2012. Renewable and Sustainable Energy Reviews, 52(December), 680-688. https://doi.org/10.1016/j.rser. 2015.07.176

Loo, Y.Y., Billa, L., \& Singh, A. (2015). Effect of climate change on seasonal monsoon in Asia and its impact on the variability of monsoon rainfall in Southeast Asia. Geoscience Frontiers, 6(6), 817-823. https://doi.org/10.1016/j.gsf.2014.02.009

Millimet, D.L., \& Roy, J. (2016). Empirical tests of the pollution haven hypothesis when environmental regulation is endogenous. Journal of Applied Econometrics, 31(4), 652-677. https:// doi.org/10.1002/jae.2451

Omri, A., Nguyen, D.K., \& Rault, C. (2014). Causal interactions between $\mathrm{CO}_{2}$ emissions, FDI, and economic growth: Evidence from dynamic simultaneous-equation models. Economic Modelling, 42(October), 382-389. https://doi.org/10.1016/j.econmod.2014.07.026 
Pao, H-T., \& Tsai, C-M. (2011). Multivariate Granger causality between $\mathrm{CO}_{2}$ emissions, energy consumption, FDI (foreign direct investment) and GDP (gross domestic product): Evidence from a panel of BRIC (Brazil, Russian Federation, India, and China) countries. Energy, 36(1), 685-693. https://doi.org/10.1016/j.energy.2010.09.041

Pata, U.K. (2018). Renewable energy consumption, urbanization, financial development, income and $\mathrm{CO}_{2}$ emissions in Turkey: Testing EKC hypothesis with structural breaks. Journal of Cleaner Production, 187(June), 770-779 https://doi.org/10.1016/j.jclepro.2018.03.236

Paul, S., \& Bhattacharya, R.N. (2004). $\mathrm{CO}_{2}$ emission from energy use in India: A decomposition analysis. Energy Policy, 32(5), 585-593. https://doi.org/10.1016/S0301-4215(02)00311-7

Pittock, A.B. (2005). Climate change: Turning up the heat. Abingdon, UK \& New York, NY: Taylor \& Francis.

Qureshi, M.A., Ahsan, T., \& Azid, T. (2017). Equity and debt financing strategies to fuel global business operations during crisis. In Hacioğlu Ü. \& Dinçer H. (Eds). Global financial crisis and its ramifications on capital markets (pp. 297-319). Cham, Switzerland: Springer. https://doi. org/10.1007/978-3-319-47021-4_22

Ren, S., Yuan, B., Ma, X., \& Chen, X. (2014). International trade, FDI (foreign direct investment) and embodied $\mathrm{CO}_{2}$ emissions: A case study of Chinas industrial sectors. China Economic Review, 28(March), 123-134. https://doi.org/10.1016/j.chieco.2014.01.003

Rowledge, L.R., Barton, R.S., Brady, K.S, Fava, J.A, Figge, C.L., Saur, K., \& Young, S.B. (2017). Mapping the journey: Case studies in strategy and action toward sustainable development. London and New York: Routledge.

Saboori, B., \& Sulaiman, J. (2013). $\mathrm{CO}_{2}$ emissions, energy consumption and economic growth in Association of Southeast Asian Nations (ASEAN) countries: A cointegration approach. Energy, 55(June), 813-822. https://doi.org/10.1016/j.energy.2013.04.038

Saboori, B., Sulaiman, J., \& Mohd, S. (2012). Economic growth and $\mathrm{CO}_{2}$ emissions in Malaysia: A cointegration analysis of the environmental Kuznets curve. Energy Policy, 51(December), 184-191. https://doi.org/10.1016/j.enpol.2012.08.065

Saito, N. (2013). Mainstreaming climate change adaptation in least developed countries in South and Southeast Asia. Mitigation and Adaptation Strategies for Global Change, 18(6), 825-849. https://doi.org/10.1007/s11027-012-9392-4

Sakai, M., \& Barrett, J. (2016). Border carbon adjustments: Addressing emissions embodied in trade. Energy Policy, 92(May), 102-110. https://doi.org/10.1016/j.enpol.2016.01.038

Salahuddin, M., Gow, J., \& Ozturk, I. (2015). Is the long-run relationship between economic growth, electricity consumption, carbon dioxide emissions and financial development in Gulf Cooperation Council Countries robust? Renewable and Sustainable Energy Reviews, 51(November), 317-326. https://doi.org/10.1016/j.rser.2015.06.005

Shahbaz, M., Nasreen, S., Abbas, F., \& Anis, O. (2015). Does foreign direct investment impede environmental quality in high-, middle-, and low-income countries? Energy Economics, 51(September), 275-287. https://doi.org/10.1016/j.eneco.2015.06.014

Shahbaz, M., Sbia, R., Hamdi, H., \& Ozturk, I. (2014). Economic growth, electricity consumption, urbanization and environmental degradation relationship in United Arab Emirates. Ecological Indicators, 45(October), 622-631. https://doi.org/10.1016/j.ecolind.2014.05.022

Shahbaz, M., Tiwari, A.K., \& Nasir, M. (2013). The effects of financial development, economic growth, coal consumption and trade openness on $\mathrm{CO}_{2}$ emissions in South Africa. Energy Policy, 61(October), 1452-1459. https://doi.org/10.1016/j.enpol.2013.07.006

Skjærseth, J.B., \& Wettestad, J. (2016). EU emissions trading: Initiation, decision-making and implementation. Abingdon, UK: Routledge.

Su, B., \& Ang, B.W. (2014). Input-output analysis of $\mathrm{CO}_{2}$ emissions embodied in trade: A multiregion model for China. Applied Energy, 114(February), 377-384. https://doi.org/10.1016/j. apenergy.2013.09.036 
Sun, M., Ravi, P., Karakiewicz, P.I., Sukumar, S., Sammon, J., Bianchi, M.,...\& Trinh, Q-D. (2014, January). Is there a relationship between leapfrog volume thresholds and perioperative outcomes after radical cystectomy? Urologic Oncology: Seminars and Original Investigations, 32(1), 27.e7-27.e13. Elsevier. https://doi.org/10.1016/j.urolonc.2012.09.012

Tang, C.F., \& Tan, B.W. (2015). The impact of energy consumption, income and foreign direct investment on carbon dioxide emissions in Vietnam. Energy, 79(January), 447-454. https:// doi.org/10.1016/j.energy.2014.11.033

Wang, Y., Li, L., Kubota, J., Han, R., Zhu, X., \& Lu, G. (2016). Does urbanization lead to more carbon emission? Evidence from a panel of BRICS countries. Applied Energy, 168(April), 375380. https://doi.org/10.1016/j.apenergy.2016.01.105

Wang, Y., Zhang, X., Kubota, J., Zhu, X., \& Lu, G. (2015). A semi-parametric panel data analysis on the urbanization-carbon emissions nexus for OECD countries. Renewable and Sustainable Energy Reviews, 48(August), 704-709. https://doi.org/10.1016/j.rser.2015.04.046

Wooldridge, J.M. (2015). Introductory econometrics: A modern approach. Toronto, Canada: Nelson Education.

World Bank. (2014). $\mathrm{CO}_{2}$ emissions (metric tons per capita). World development indicators. The World Bank Group. https://data.worldbank.org/indicator/EN.ATM.CO2E.PC. Retrieved 24 July 2018.

World Bank. (2012). Total greenhouse gas emissions ( $\mathrm{kt}$ of $\mathrm{CO}_{2}$ equivalent). World development indicators. The World Bank Group. https://data.worldbank.org/indicator/EN.ATM.GHGT. KT.CE. Retrieved 24 July 2018.

Wu, R., Geng, Y., Dong, H., Fujita, T., \& Tian, X. (2016). Changes of $\mathrm{CO}_{2}$ emissions embodied in China-Japan trade: drivers and implications. Journal of Cleaner Production, 112(Part 5), 4151-4158. https://doi.org/10.1016/j.jclepro.2015.07.017

Wu, Y., Shen, J., Zhang, X., Skitmore, M., \& Lu, W. (2016). The impact of urbanization on carbon emissions in developing countries: A Chinese study based on the U-Kaya method. Journal of Cleaner Production, 135(November), 589-603. https://doi.org/10.1016/j.jclepro.2016.06.121

$\mathrm{Xu}, \mathrm{R} .$, \& Lin, B. (2017). Why are there large regional differences in $\mathrm{CO}_{2}$ emissions? Evidence from China's manufacturing industry. Journal of Cleaner Production, 140(Part 3), 1330-1343. https://doi.org/10.1016/j.jclepro.2016.10.019

Yang, L., \& Li, Z. (2017). Technology advance and the carbon dioxide emission in China - Empirical research based on the rebound effect. Energy Policy, 101(February), 150-161. https://doi. org/10.1016/j.enpol.2016.11.020

Yunfeng, Y., \& Laike, Y. (2010). China's foreign trade and climate change: A case study of $\mathrm{CO}_{2}$ emissions. Energy Policy, 38(1), 350-356. https://doi.org/10.1016/j.enpol.2009.09.025

Zaman, K., \& Abd-el Moemen, M. (2017). Energy consumption, carbon dioxide emissions and economic development: Evaluating alternative and plausible environmental hypothesis for sustainable growth. Renewable and Sustainable Energy Reviews, 74(July), 1119-1130. https://doi.org/10.1016/j.rser.2017.02.072

Zaman, K., Shahbaz, M., Loganathan, N., \& Raza, S.A. (2016). Tourism development, energy consumption and Environmental Kuznets Curve: Trivariate analysis in the panel of developed and developing countries. Tourism Management, 54(June), 275-283. https://doi.org/ 10.1016/j.tourman.2015.12.001

Zhang, Y. (2012). Scale, technique and composition effects in trade-related carbon emissions in China. Environmental and Resource Economics, 51(3), 371-389. https://doi.org/10.1007/ s10640-011-9503-9

Zhang, Y-J., Liu, Z., Qin, C-X., \& Tan, T-D. (2017). The direct and indirect $\mathrm{CO}_{2}$ rebound effect for private cars in China. Energy Policy, 100(January), 149-161. https://doi.org/10.1016/j.enpol. 2016.10.010 
Zhang, Y-J., Liu, Z., Zhang, H., \& Tan, T-D. (2014). The impact of economic growth, industrial structure and urbanization on carbon emission intensity in China. Natural Hazards, 73(2), 579-595. https://doi.org/10.1007/s11069-014-1091-x

Zhu, H., Duan, L., Guo, Y., \& Yu, K. (2016). The effects of FDI, economic growth and energy consumption on carbon emissions in ASEAN-5: Evidence from panel quantile regression. Economic Modelling, 58(November), 237-248. https://doi.org/10.1016/j.econmod.2016. 05.003

Zimmer, A., Jakob, M., \& Steckel, J.C. (2015). What motivates Vietnam to strive for a low-carbon economy? - On the drivers of climate policy in a developing country. Energy for Sustainable Development, 24(February), 19-32. https://doi.org/10.1016/j.esd.2014.10.003 